\title{
Prevalence of nematodes infestation in Clarias gariepinus from El-Burullus Lake and Lake Nasser, Egypt
}

\author{
Sh.S. Sorour ${ }^{1}$ and A.H. Hamouda ${ }^{2}$ \\ ${ }^{1}$ Parasitology Department, Faculty of Veterinary Medicine, Kafr El-Sheikh University, Kafr El-Sheikh 33516, \\ ${ }^{2}$ Department of Fish Diseases, Faculty of Fish and Fisheries Technology, Aswan University, postal code: 81528, Egypt \\ *Corresponding Author: awatefhamouda@yahoo.com; awatefhamouda@aswu.edu.eg
}

(Received March 11, 2018; Accepted April 26, 2019)

\begin{abstract}
A total number of 400 Clarias gaiepinus were collected alive from several and various locations at El-Burullus Lake and Lake Nasser, to investigate the prevailing nematodes that infect this fish species from the two locations. Nearly all the examined fish were positive for one or more nematodes; four spp. of two families were identified from Clarias gaiepinus at ElBurullus Lake: Procamallanus laeviconchus, Paracamallanus cyathopharynx, Neocamallanus spp. (recovered from the gall bladder for the first time) and Terranova spp. larvae (recorded for the first time in Kafr El-Sheikh Governorate representing new locality record), one nematode from Clarias gaiepinus at Lake Nasser: $3^{\text {rd }}$ stage larvae $\left(\mathrm{L}_{3}\right)$ of Contraceacum spp. (has zoonotic importance). The prevalence of Procamallanus laeviconchus, Paracamallanus cyathopharynx, Neocamallanus spp. and Terranova spp. larva were $37.5 \%, 44 \%, 0.5 \%$ and $10 \%$ respectively, meanwhile the prevalence of $\mathrm{L}_{3}$ larvae of Contraceacum spp. were $100 \%$. This study was planned to compare between the nematodes infecting Clarias gaiepinus from the two lakes evaluating clinical signs, postmortem examinations, parasitological examinations, seasonal prevalence and histopathological investigations of infected fish with different nematodes infestation. Clarias gaiepinus must be eviscerated as soon as possible after catching to prevent $3^{\text {rd }}$ stage larvae of Contraceacum spp. in the abdominal cavity from liberating from their sheaths and attacking the fish musculature (the edible part in the fish) as well as, prevent Terranova spp. larvae in the gills from attacking another parts of the fish and thus prevent the transmission of the nematodes of zoonotic importance to the consumers.
\end{abstract}

Keywords: Catfish, Terranova spp., Neocamallanus spp., Contracaecum spp., Pathology Available online at http://www.vetmedmosul.com

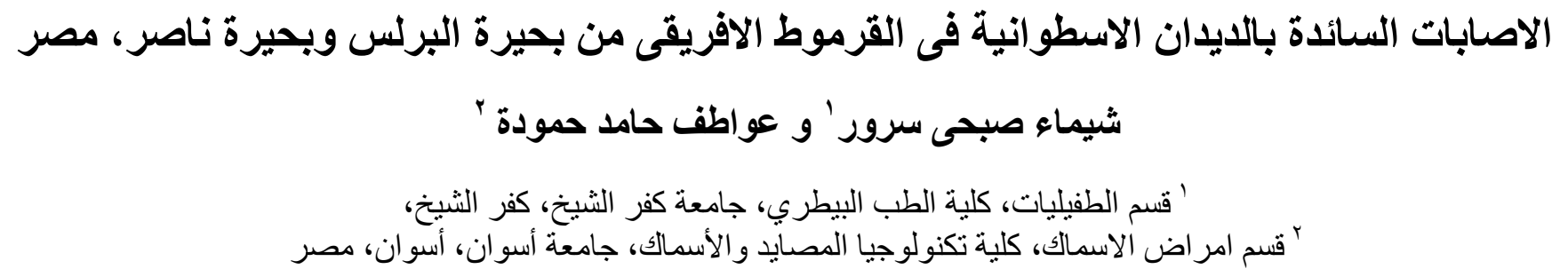

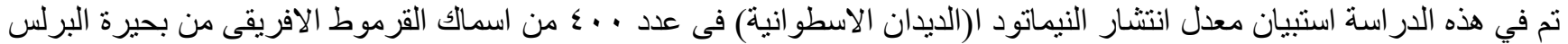

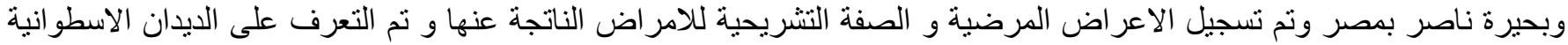

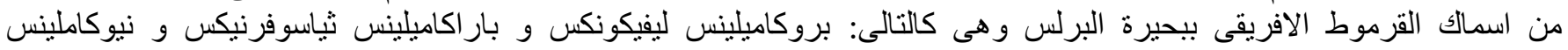

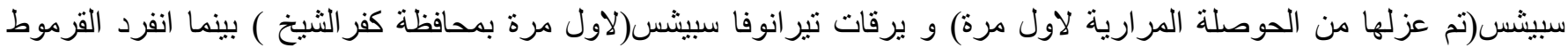

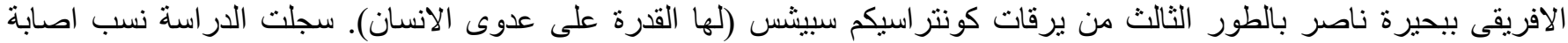

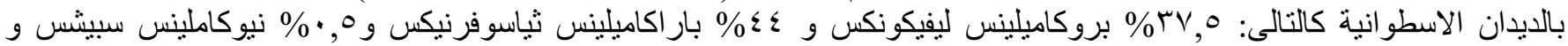




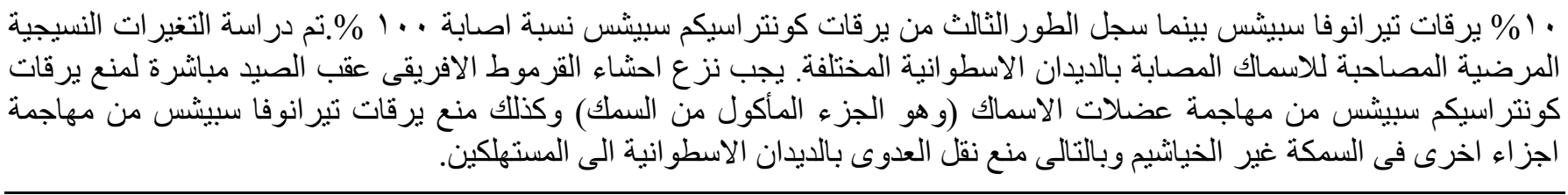

\section{Introduction}

The African catfish; Clarias gariepinus is a widely distributed fish food in Africa (1) of high growth rate and excellent meat quality (2). It has a great potential as a protein and energy sources in human nutrition and its lipids are a good source for polyunsaturated fatty acids, especially what is known as omega 3 fatty acids (3).

Clarias gariepinus in many African countries is an important solution to the increasing demand for fish and fish products in response to rapid human population growth and the fear of animal-related disease outbreaks e.g., avian and swine influenza (4).With the growing of the economic value of Clarias gariepinus, the interest in its parasitic loads and its impact on the fish increased (5).

Fish diseases constitute one of the most important challenges confronting fish industry in both natural and culture environments especially parasitic one which has a serious impact on the fish as they cause mortality, low growth rate, lower food conversion rates and decreased marketability as well as it may has zoonotic threats, to human consumers (6-8).

About 650 species of nematodes parasitize fish as adults and many others nematodes use fish as intermediate hosts (9).The nematodes cause damage to the hosts by depriving them of digested food and by feeding on host tissues, sera, or blood. In some cases, direct mechanical damage results from their fixing to host tissues and developing or migrating in them $(10,11)$. Small numbers of nematodes often occur in healthy fish, but high numbers cause illness or even death (12).

Contracaecosis and pseudoterranovosis are parasitic diseases caused by infestation with larval nematodes of the taxonomic genus Contracaecum and terranova respectively which belong to the family, Anisakidae $(13,14)$. They are zoonotic diseases with medical and economic importance and can result in considerable costs to the fishing industry. Humans are accidentally infected by consuming raw, poorly cooked (15), cold smoked or lightly salted fish (16).

The aim of the present study is to carry out as a reconnaissance survey of the nematodes infestation in Clarias gariepinus from both El-Burullus Lake and Lake Nasser, which can be used in the fish health assessment recording the clinical signs, the postmortem changes, the total and the seasonal prevalence, as well as the histopathological alterations in the infected fish.

\section{Material and methods}

\section{Study areas}

El-Burullus Lake is a brackish water lake and is the second largest Egyptian northern lake along the Mediterranean coast. It is located in the central part of the northern shoreline of the Nile Delta. The lake is shallow, with a maximum depth of $175 \mathrm{~cm}$ in the middle and western parts. The lake surface area is $410 \mathrm{~km}^{2}$.

Lake Nasser, together with Lake Nubia, is the second largest man-made lake in Africa created as a result of the construction of the Aswan High Dam in the 1960's on the River Nile. Lake Nasser extends $300 \mathrm{~km}$ within the Egyptian borders and is now one of the most important sources of freshwater fish in Egypt.

\section{Fish samples}

A total number of 400 Clarias gaiepinus of different weights and sizes were collected, randomly and alive, from two different ecosystems; 200 Clarias gariepinus from ElBurullus Lake and 200 from Lake Nasser during 2017. The collected fish were transferred alive and kept in prepared glass aquaria in the laboratory of Parasitology, Faculty of Veterinary Medicine, Kafrelsheikh University and the laboratory of Fish Diseases, Faculty of Fish and Fisheries Technology, Aswan University respectively.

\section{Clinical and postmortem examinations}

The fish was subjected to full clinical examination; the external and internal gross lesions were recorded immediately according to the method described by (17).

\section{Parasitological examinations}

Parasitological examinations were performed and then the collected parasites were washed, fixed and mounted according to the methods described by $(17,18)$.

\section{Identification of collected helminthes}

The collected nematodes were identified according to the identification keys of (19-22).

\section{Histopathological examination}

After necropsy, sections of stomach, intestine, kidney and muscles (parts of abdominal and trunk muscles closely situated to $3^{\text {rd }}$ stage larvae of Contracaecum spp. in the abdominal cavity of infected fish) were fixed immediately 
in $10 \%$ formalin and processed for histopathological evaluation as described by (23).

\section{Results and discussion}

\section{Clinical and postmortem examinations}

The fish infested with small numbers of nematodes showed no pathognomonic lesions while the severely infected ones showed emaciation and this may be due to the adult nematodes in the stomach and intestinal tract damage its lining and rob the nutrients of the fish (12), as well as the mechanical pressure along the gastrointestinal tract in which the parasites attached from outside; causing a wasting effect. Dark or pale body coloration could be recorded and hemorrhagic patches may be found on some infected fish.

The gills of fish naturally infected with the microscopic nematodes showed paleness with excessive mucus which may be a defensive mechanism to diminish the irritant effect of the pathogenic nematodes.

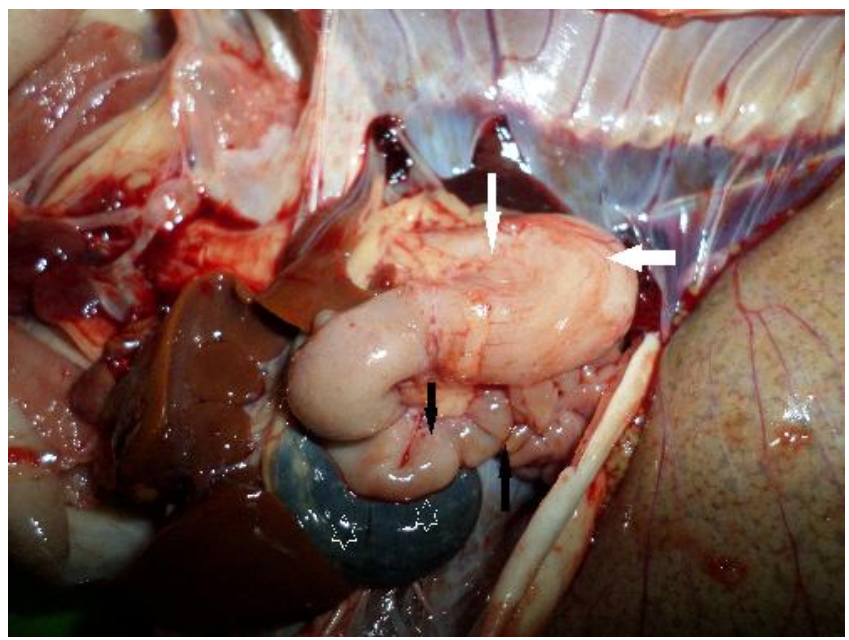

Figure 1: Clarias gariepinus from El Burullus Lake infected with Procamallanus laeviconchus and Paracamallanus cyathopharynx showing: Congestion and hemorrhages of the stomach (white arrows) and intestine (black arrows) as well as distended gall bladder (white stars).

Stomach and intestine were congested (Fig. 1, Fig. 2) and this may be attributed to the firm attachment of the nematodes (Procamallanus laeviconchus and Paracamallanus cyathopharynx) to them; embedding their buccal capsule between the villi of the lining mucosa; causing local damage and possibly peritonitis in addition to $3^{\text {rd }}$ stage larvae of Contracaecum which attached along the alimentary tract causing tissue destructions or alterations. Moreover, proteolytic enzymes discharged from adult worms may be degrading the gastric and intestinal tissues (24). Helminthes produce toxic metabolic by-products which harm the infected host by causing occlusion of blood vessels, intestine and other ducts and resulting in the inflammation and congestion described in the internal organs. Visible nematodes could be seen by the naked eye in the abdominal cavity (Fig. 2) and this result is similar to that recorded by (25), these nematodes will liberate from their fibrin sheaths and invade the internal organs and the musculature if the fish do not eviscerate as soon as possible after catching. Also the gall bladder, the stomach and the intestine of fish are infected with smaller visible nematodes as that recorded in the stomach and the intestine of Clarias gariepinus by (26).

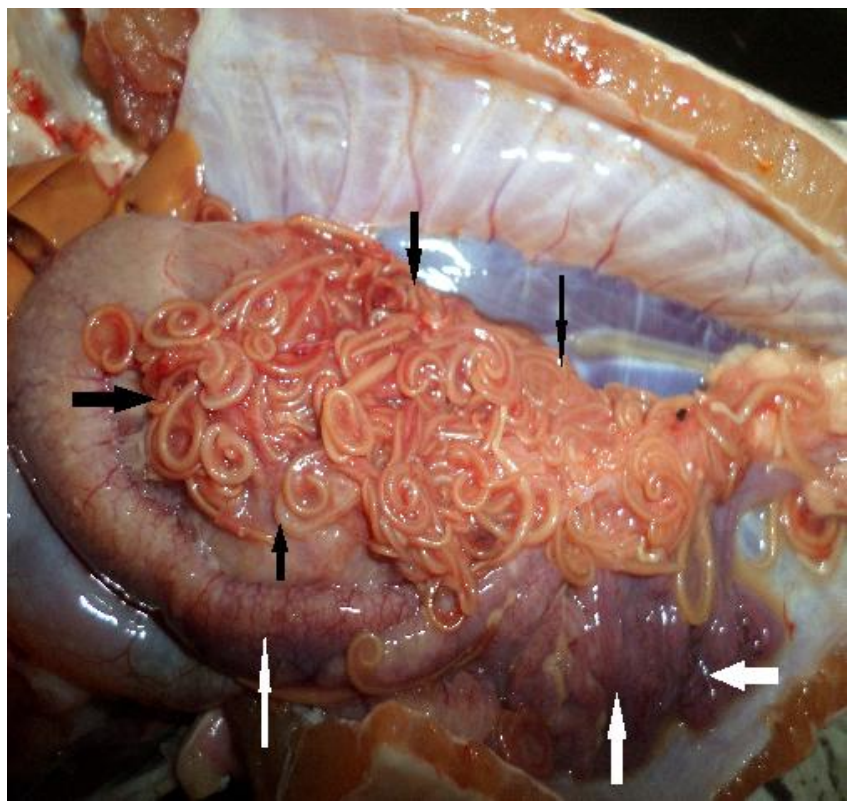

Figure 2: Clarias gariepinus from Lake Nasser infected with ${ }^{\text {rd }}$ stage larvae of Contracaecum spp. showing: $3^{\text {rd }}$ stage larvae of Contracaecum spp. attached to the alimentary canal and the mesentry (black arrows) and congested intestine (white arrows).

\section{Parasitological examinations}

Based on the morphological examination, the following nematodes were identified from Clarias gariepinus at ElBurullus Lake, Kafr El Sheikh Governorate.

Procamallanus laeviconchus (Fig. 3: a, b, c, d) was isolated from the stomach and the intestine of Clarias gariepinus. It is small ovoviviparous nematode, yellowish in color with continuous buccal capsule, not separated into paired lateral-valves, the wall may be smooth or with spiral markings internally. The uterus of mature female is filled with larvae. Such adult nematodes are belonged to family Camallanidae (27-29). 
Paracamallanus cyathopharynx (Fig. 4: a, b) was isolated from the stomach and the intestine of Clarias gariepinus. It is cylindrical, yellowish brown in color with transverse annulations and the buccal capsule is consisting of two lateral valves with a large chitinous buccal cavity or pharynx behind the valves; the trident is present. The tail is tapering in female and curved in male. Such adult nematodes are belonged to family Camallanidae $(27,29)$.

The microscopic larval nematode, Terranova sp. (Fig. 5: $\mathrm{a}, \mathrm{b})$ isolated for the first time from the gills of Clarias gariepinus in Kafr El Sheikh Governorate and considered as a new locality record. The genus Terranova was erected by Leiper and Atkinson (30). Terranova was later considered as a synonym of Phocanema and Pseudoterranova (20). Our Terranova sp. larva is very small and cannot be seen by the naked eyes. Their lips are with dentigerous ridges. The ventriclus and the intestinal cecum are present with no ventricular appendix. Such larval nematodes are belonged to family Anisakidae (22).

The nematode Neocamallanus spp. (Fig. 6) isolated for the first time from the gall bladder of Clarias gariepinus. It is transparent with buccal capsule consisting of two lateral valves, but without tridents or rods associated with it. A strongly developed chtinious is present behind the buccal valves. Such adult nematodes are belonged to family Camallanidae (19).
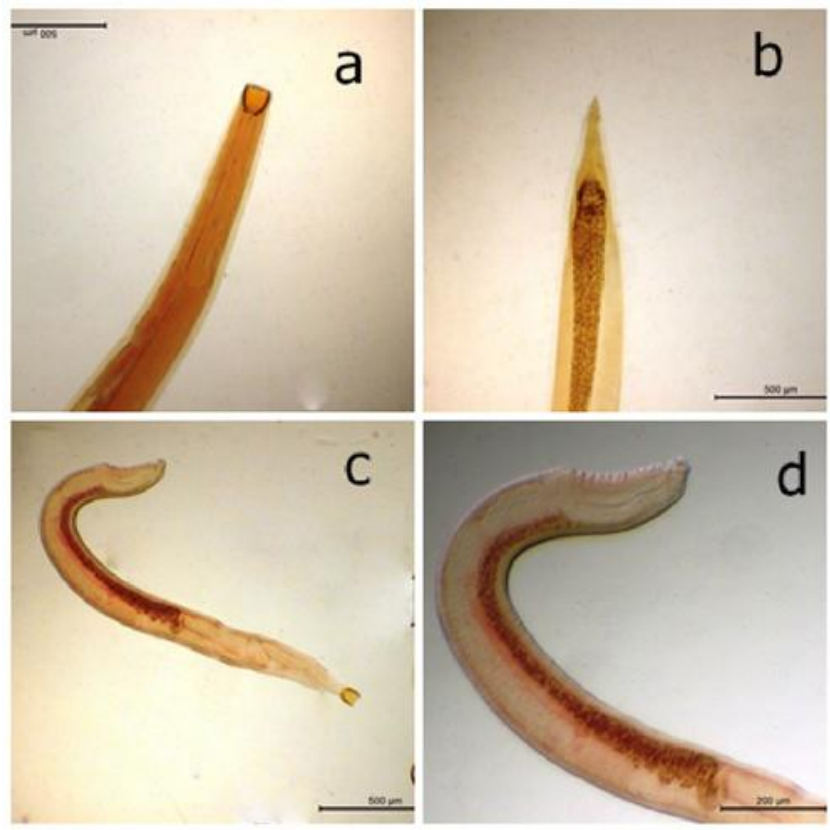

Figure 3: Procamallanus laeviconchus isolated from stomach and intestine of Clarias gariepinus of El-Burullus Lake. (a) Anterior end x 500. (b) Female posterior end x 500. (c) Male whole worm x 500. (d) Male posterior end x 200.

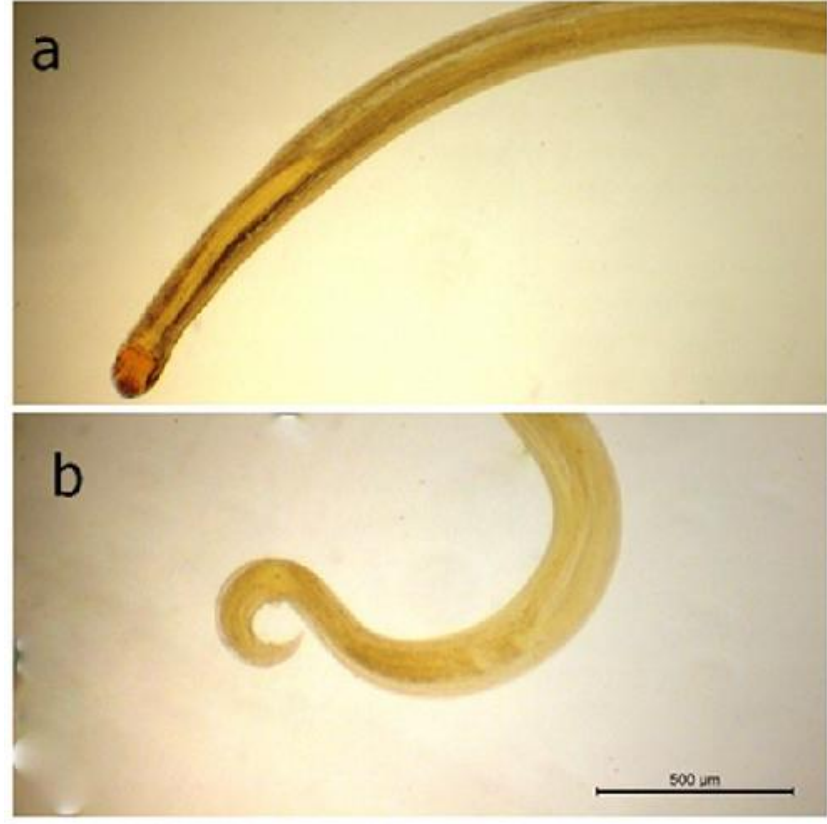

Figure 4: Paracamallanus cyathopharynx isolated from stomach and intestine of Clarias gariepinus of El-Burullus Lake. (a): Anterior end x 500. (b): Male posterior end x 500 .

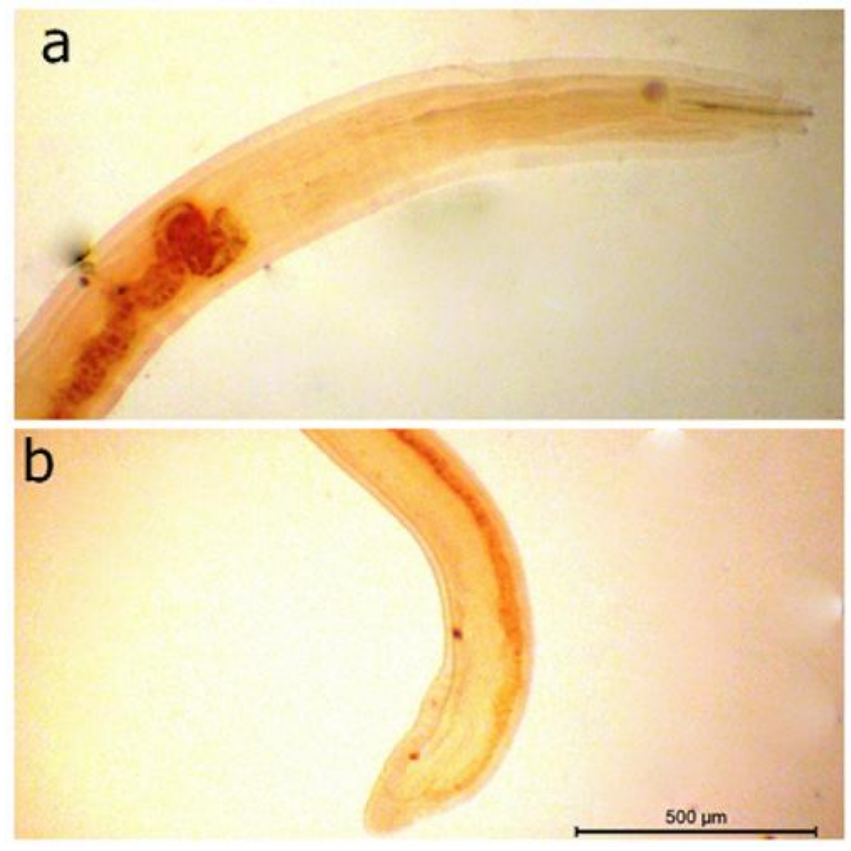

Figure 5: Terranova spp. isolated from the gills of Clarias gariepinus of El-Burullus Lake (a): Anterior end x 500. (b): Posterior end $\mathrm{x} 500$. 


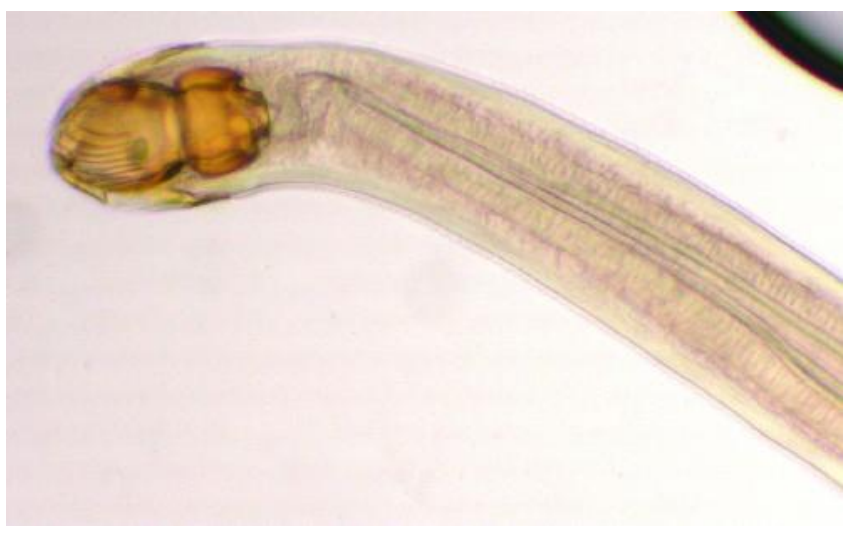

Figure 6: Anterior end of Neocamallanus spp. isolated from the gall bladder of Clarias gariepinus of El-Burullus Lake $\mathrm{x}$ 400 .

The only nematode isolated from Clarias gariepinus at Lake Nasser, Aswan Governorate was: The $3^{\text {rd }}$ stage larva of Contracaecum spp. (Fig. 7: a, b) in the abdominal cavity encapsulated in a fibrin sheath and attached to the alimentary canal. It is yellowish-red in color with long, cylindrical body. The cuticle is smooth and transversely striated with regular and irregular ring forms. The anterior end is rounded, while the posterior one is pointed. The mouth is surrounded by three small lips with a prominent papilla. The oesophagus is narrow and long. Two blind caeca are branching off from the intestinal tract at the junction of the oesophagus and the midgut. The ventricular appendix is shorter and pointing posteriorly while the intestinal caecum is longer and pointing anteriorly. The anus is located near the posterior end. The tail is conical in shape with a tapered spine. Such larval nematodes are belonged to family Anisakidae $(25,28)$.

\section{The total and seasonal prevalence of detected parasites:}

Clarias gariepinus from El Burullus Lake revealed a nematodal infection rate with prevalence of $62 \%$ of the examined fish.

The total prevalence of Procamallanus laeviconchus and Paracamallanus cyathopharynx are $37.5 \%$ and $44 \%$ (Table 1) showing high prevalence in summer $(70,80 \%)$, spring $(36,40 \%)$, autumn $(28,28,23 \%)$ then winter $(16$, $24 \%$ ) respectively (Table 2 ) and this result is higher than that recorded by (29) who isolated Procamallanus laeviconchus and Paracamallanus cyathopharynx with prevalence of $26 \%$ and $31 \%$ showing high prevalence also in summer $(48 \%, 56 \%)$ and low prevalence in winter $(4 \%$ and $8 \%$ ) respectively at Ismailia Governorate, Egypt. Also our results are higher than that recorded by (31) who detected Procamallanus laevionchus from Clarias gariepinus with prevalence of $23.33 \%$ in Lake Manzala, Egypt. Procamallanus laeviconchus and Paracamallanus cyathopharynx were isolated from Clarias gariepinus with prevalence of $8.74 \%$ and $55.33 \%$ respectively in Nigeria (32) which differ completely with our results. This variation may be attributed to the different ecological factors in the different localities which usually enhance or limit the parasites spread as well as, the different sources of the examined fish, the type, the age and the sex of the examined fish.

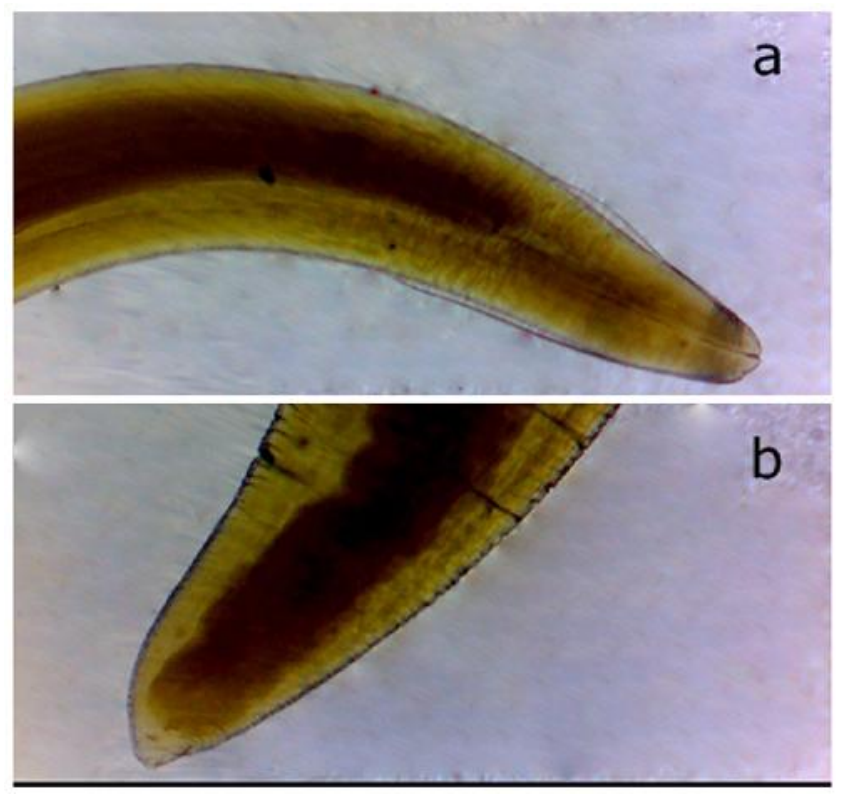

Figure 7: $3^{\text {rd }}$ stage larva of Contracaecum spp. (a): Anterior end $\mathrm{x} 500$. (b): Male posterior end x 500 .

Increase infestation in summer may be due to increase the feeding activity of the fish at high temperatures and the intermediate host is more abundant during these warmer months; increasing the chances of infection via copepods ingestion and vice versa (33).

The life cycle of Paracamallanus cyathopharynx and Procamallanus laeviconchus in Egypt were studied previously by $(21,34)$ and found that the Copepoda; Mesocyclops leukarti harbors the first 3 larval stages of both these nematodes. The copepod must then be ingested by Clarias gariepinus to continue the life cycle. This assumption is strengthened by the feeding habits of catfish which is a voracious omnivore, with predator tendencies, eating animal matter of any sort which in turn assists the transmission of more helminthes through their feeding on aquatic animals harboring the infective stages of these parasites or even the young infected fish. Moreover the leathery skin of Clarias gariepinus may be attacked easily by leeches and copepods and this explain the recorded hemorrhagic lesions on skin and fins of some infected fish (35). 
The microscopic larval nematode; Terranova spp. in the gills of Clarias gaiepinus with an overall prevalence of $10 \%$ (Table 1), a higher infection rate is in summer $22 \%$, spring $8 \%$, winter $6 \%$ and then autumn $4 \%$ (Table 2 ).

The Neocamallanus spp. isolated from the gall bladder of Clarias gaiepinus is only one and recovered in summer (Table 1, 2).

To our knowledge, no one recovered Terranova sp. from Clarias gariepinus in Kafr El Sheikh Governorate before although (36) listed seven marine fish species parasitized by Terranova sp. in the Red Sea fish in Egypt. It is safe to assume that Terranova can be found wherever suitable hosts live and favorable environmental conditions permit (14).

3rd stage larvae of Contracaecum spp. are found throughout the period of study in Clarias gariepinus of Lake Nasser with a prevalence of $100 \%$ (Table 1). This makes Contracaecum the most prevalent fish nematodes in Lake Nasser and the fact that its life cycle involves migratory bird species (as cormorants) can justify this observation as well as, in Aswan the high temperature is maintained nearly throughout the year; this favors the development of both the invertebrate hosts and the final hosts throughout the year around the Lake and increase the plankton production, which is the source of nutrition of intermediate hosts. This result is similar to that recorded by (25) from Clarias gariepinus of Lake Nasser and higher than that recorded by (37) who found $42.6 \%$. of Clarias gariepinus infected with $3^{\text {rd }}$ stage larvae of Contracaecum spp. from Lake Chivero, Zimbabwe as well as, (28) who declared that Clarias gariepinus infected with $86 \%$ Contracaecum spp. in South Africa and (38) who observed Contracaecum spp. from $9.9 \%$ of the examined Clarias gariepinus in Cameroon.

The nematodes recorded in Clarias gariepinus of El Burullus Lake, kafr El Sheikh Governorate are completely different from that of Lake Nasser, Aswan Governorate this may be due to that the climate change might have a direct effect on the parasite species and also have indirect effects through changes in the distribution and abundance of their intermediate and final hosts (39) in addition to the different ecological factors in the two localities.

\section{Histopathological examination}

The histopathological examination of Clarias gariepinus infested with Procamallanus laeviconchus, Paracamallanus cyathopharynx revealed multifocal lymphocytic enteritis as well as intestinal atrophied crypts (Fig. 8-A). This result is nearly similar to that reported by (29).

Table 1: Prevalence of nematodes among the examined Clarias gariepinus from El Burullus Lake and Lake Nasser at 2017

\begin{tabular}{|c|c|c|c|c|c|c|c|c|c|c|c|}
\hline \multirow{3}{*}{$\begin{array}{l}\text { Fish species } \\
\text { (location of the fish) }\end{array}$} & \multicolumn{11}{|c|}{ Nematodes } \\
\hline & \multirow{2}{*}{ 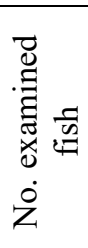 } & \multicolumn{2}{|c|}{$\begin{array}{l}\text { Procamallanus } \\
\text { laeviconchus }\end{array}$} & \multicolumn{2}{|c|}{$\begin{array}{l}\text { Paracamallanus } \\
\text { cyathopharynx }\end{array}$} & \multicolumn{2}{|c|}{$\begin{array}{c}\text { Terranova } \\
\text { spp. larva }\end{array}$} & \multicolumn{2}{|c|}{$\begin{array}{l}\text { Neocamallanus } \\
\text { spp. }\end{array}$} & \multicolumn{2}{|c|}{$\begin{array}{c}3^{\text {rd }} \text { stage larva of } \\
\text { Contracaecum spp. }\end{array}$} \\
\hline & & 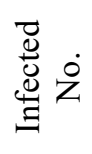 & 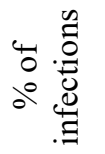 & 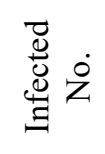 & 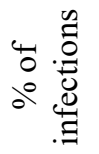 & 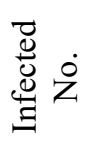 & 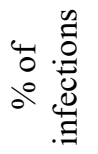 & 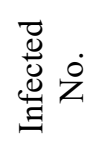 & 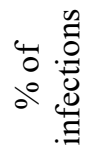 & 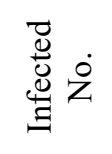 & 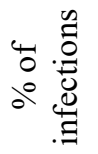 \\
\hline $\begin{array}{l}\text { Clarias gariepinus } \\
\text { (El Burullus Lake) }\end{array}$ & 200 & 75 & 37.5 & 88 & 44 & 20 & 10 & 1 & 0.5 & 0 & 0 \\
\hline $\begin{array}{l}\text { Clarias gariepinus } \\
\text { (Lake Nasser) }\end{array}$ & 200 & 0 & 0 & 0 & 0 & 0 & 0 & 0 & 0 & 200 & 100 \\
\hline
\end{tabular}

Table 2: Seasonal prevalence of different nematodes in Clarias gariepinus from El Burullus Lake during 2017

\begin{tabular}{|c|c|c|c|c|c|c|c|c|c|}
\hline \multirow{3}{*}{ Season } & \multicolumn{9}{|c|}{ Nematodes } \\
\hline & \multirow{2}{*}{$\begin{array}{c}\text { No. } \\
\text { examined } \\
\text { Fish }\end{array}$} & \multicolumn{2}{|c|}{$\begin{array}{c}\text { Procamallanus } \\
\text { laeviconchus }\end{array}$} & \multicolumn{2}{|c|}{$\begin{array}{l}\text { Paracamallanus } \\
\text { cyathopharynx }\end{array}$} & \multicolumn{2}{|c|}{$\begin{array}{c}\text { Terranova spp. } \\
\text { larva }\end{array}$} & \multicolumn{2}{|c|}{ Neocamallanus spp. } \\
\hline & & $\begin{array}{c}\text { No. of } \\
\text { infected fish }\end{array}$ & $\begin{array}{c}\% \text { of } \\
\text { infection }\end{array}$ & $\begin{array}{c}\text { No. of } \\
\text { infected fish }\end{array}$ & $\begin{array}{c}\% \text { of } \\
\text { infection }\end{array}$ & $\begin{array}{c}\text { No. of } \\
\text { infected fish }\end{array}$ & $\begin{array}{c}\% \text { of } \\
\text { infection }\end{array}$ & $\begin{array}{c}\text { No. of } \\
\text { infected fish }\end{array}$ & $\begin{array}{c}\% \text { of } \\
\text { infection }\end{array}$ \\
\hline Spring & 50 & 18 & 36 & 20 & 40 & 4 & 8 & 0 & 0 \\
\hline Summer & 50 & 35 & 70 & 40 & 80 & 11 & 22 & 1 & 2 \\
\hline Autumn & 50 & 14 & 28 & 16 & 32 & 2 & 4 & 0 & 0 \\
\hline Winter & 50 & 8 & 16 & 12 & 24 & 3 & 6 & 0 & 0 \\
\hline Total & 200 & 75 & 37.5 & 88 & 44 & 20 & 10 & 1 & 0.5 \\
\hline
\end{tabular}


Clarias gariepinus infested with $3^{\text {rd }}$ stage larvae of Contracaecum spp. showed varying degrees of pathological changes including lymphocytic enteritis with presence of dead cyst (Fig. 8-B) like that recorded by (40) who declare the effect of L3 of Contracaecum spp. on Lates niloticus. The kidney showed interstitial lymphocytic nephritis accompanied with severe diffuse lymphocytic infiltration (Fig. 8-C) and multiple interstitial hemorrhages (Fig. 8-D). The skeletal muscle showed myositis associated with perivascular lymphocytic and plasma cells infiltration (Fig. 8-F).
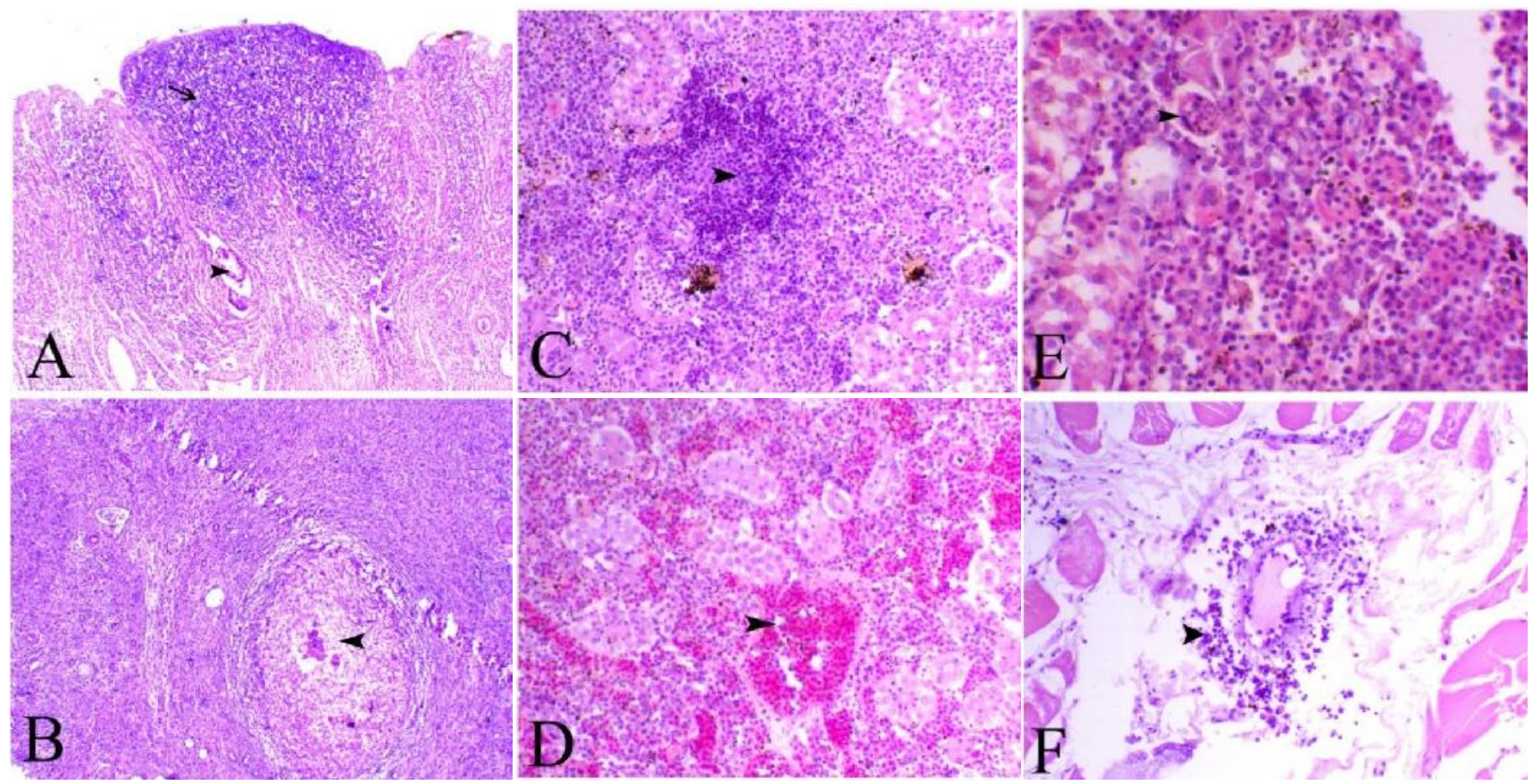

Figure 8. Clarias gariepinus infected with Procamallanus laeviconchus, Paracamallanus cyathopharynx or $3^{\text {rd }}$ stage larvae of Contracaecum spp. from El Burullus Lake and Lake Nasser during 2017showing: (A): Intestine infected with Procamallanus laeviconchus and Paracamallanus cyathopharynx showing multifocal lymphocytic enteritis (arrow) (arrowhead indicates atrophied crypts) H\&E, x 100. (B): Intestine infected with L3 of Contracaecum spp. showing lymphocytic enteritis with presence of dead cysts (arrowhead) H\&E, x 40. (C): The kidney of Clarias gariepinus infected with L3 of Contracaecum spp. showing features of interstitial lymphocytic nephritis (arrowhead) accompanied with severe diffuse lymphocytic infiltration, H\&E, x 100. (D): Kidney of Clarias gariepinus infected with L3 of Contracaecum spp. with interstitial haemorrhage (arrowhead) H\&E, x 100. (E): Kidney of Clarias gariepinus infected with L3 of Contracaecum spp. with parasitic cyst (arrowhead) H\&E, x 200. (F): The musculature of Clarias gariepinus infected with L3 of Contracaecum spp. showed myositis associated with perivascular lymphocytic and plasma cells infiltration (arrowhead) H\&E, x 200.

\section{Conclusion}

Nematodal infection of Clarias gariepinus is an important factor affecting wild populations of Clarias gariepinus in El-Burullus Lake and Lake Nasser. Therefore, extended investigations about their effects on the survival, the growth and the fecundity of this fish species are recommended to ensure successful fishery management plans.

Clarias gariepinus must be eviscerated as soon as possible after catching to avoid the attack of $3^{\text {rd }}$ stage larvae of Contracaecum spp. in the abdominal cavity to the fish muscle (the edible part in the fish) and disrupt the life cycles of the other detected nematodes. The disposal of viscera or infected fish parts in water should be strenuously prohibited. Regular monitoring of the fish in both lakes is a must. Further studies on Terranova spp. in Clarias gariepinus (new locality record) are needed.

\section{References}

1. Olufemi BE, Akinlabi DA, Agbede SA. Aerobic Bacterial Pathogens Isolated from the African Catfish Clarias gariepinus. Tropical Veterinarian. 1991; 9:177-180. 
2. El-Naggar GO, John G, Rezk MA, Elwan W, Yehia M. Effect of varying density and water level on spawning response of African catfish Clarias gariepinus:implication for seed production. Aquacult. 2006; 261:904-907.

3. Hoffman IC, Prinsloo JF. The potential of freshwater fish in South Africa. Food Industries of South Africa. 1996; 30:1-2.

4. Chibwana FD, Nkwengulila G, Locke SA, McLaughlin JD, Marcogliese DJ. Completion of the life cycle of Tylodelphys mashonense (Sudarikov, 1971) (Digenea:Diplostomidae) with DNA barcodes and rDNA sequences. Parasitol Res. 2015; 114(10):36753682. Doi: 10.1007/s00436-015-4595-8.

5. Ghoneim W, Khalil R, Saad T, Tanekhy M, Abdel-Latif H. Ectoparasite fauna of cultured African catfish, Clarias gariepinus (Burchell, 1822), El-Behera Province, Egypt. Int J Fisheries Aquatic Stud. 2015; 3(1):19-22.

6. Noga EJ. Fish diseases: Diagnosis and treatment. Iowa State University Press; 2000.

7. Woo PT. Fish Diseases and Disorders: Protozoan and Metazoan Infections, Second Edition, Volume 1. CAB International; 2006.

8. Elsheikha HM, Elshazly AM. Host-dependent variations in the seasonal prevalence and intensity of heterophyid encysted metacercariae (Digenea: Heterophyidea) in brackish water fish in Egypt. Vet Parasitol. 2008; 153:65-72.

9. Williams H, Jones A. Parasitic worms of fish. Folia Parasitologica. 1994; 41:38.

10. Dick TA, Choudhury A. Phylum nematoda. In:Woo PTK, editor. Fish Diseases and Disorders. I. Protozoan and metazoan infections. Wallingford, Oxon, UK: CAB International; 1995.

11. Moravec F. Parasitic Nematodes of Freshwater Fishes of Europe. Dordrecht/Boston/London: Kluwer Academic Publishers. 1994.

12. Yanong RPE. Nematode (Roundworm) Infections in Fish [dissertation]. USA: University of Florida, IFAS Extension, Cir 91; 2017.

13. Shamsi, Suthar. Occurrence of Terranova larval types (Nematoda:Anisakidae) in Australian marine fish with comments on their specific identities. Peer J. 2016; 4:e1722; DOI 10.7717/peerj. 1722 .

14. Measures LN. Anisakiosis and pseudoterranovosis: Reston, Va., U.S. Geological Survey Circular 1393, 34 p., 2 appendixes. 2014. http://dx.doi.org/10.3133/cir1393.

15. Chai J-Y, Darwin Murrell K, Lymbery AJ. Fish-borne parasitic zoonoses: status and issues. International Journal for Parasitology. 2005; 35:1233-1254. Doi: 10.1016/j.ijpara.2005.07.013

16. Younis AE, Saad AI and Rabei JM. The occurrence of Contracaecum sp. larvae (Nematoda:Anisakidae) in four teleostean species from Lake Nasser, Egypt: morphological and molecular studies. J Basic Appl Zool. 2017;78:9. DOI 10.1186/s41936-017-0012-4

17. Noga EJ. Fish disease:diagnosis and treatment $/ 2^{\text {nd }}$ ed. USA: Wileyblackwell Publishing;2010.

18. Lucky Z. Methods for the diagnosis of fish diseases. New Delhi, Bombay, Calcutta and New York: Amerind publishing Co, PTV. LTD; 1977.

19. Yamaguti S. Systema Helminthum Vol. III, parts 1 and 2. The nematodes of vertebrates. New York: Interscience. Publ. 1961

20. Hartwich G. Keys to genera of the Ascaridoidea. In: Anderson RC, Chabaud AG, Willmott S, editors. CIH Keys to the nematode parasites of vertebrates. Farnham Royal, Bucks., England: Commonwealth Agricultural Bureaux; 1974.p. 1-15.

21. Moravec F. The development of Procamallanus laeviconchus (Wedl, 1862) (Nematoda: Camallanidae). Vestnik Ceskoslovenske Spolecnosti Zoologicke.1975; 34, 23-38.

22. Anderson RC. Nematode Parasites of Vertebrates: Their Development and Transmission. $2^{\text {nd }}$ ed. UK: CABI publishing; 2000.
23. Bancroft JD, Gamble M. Theory and Practice of Histological Techniques. $5^{\text {th }}$ Edition. UK, London: Churchill Livingstone; 2007: 125-138p.

24. Woo PTK. Fish Diseases and Disorders. I. Protozoan and metazoan infections. Wallingford, Oxon, UK: CAB International; 1995.

25. Gihan MR. Light and Scanning Electron Microscopy studies on Contracaecum sp. larvae and Cithariniella citharini (Nematoda) from Lake Nasser fishes. [Master's thesis]. Egypt: South Valley University; 2009.

26. Bassiony AE. Studies on the prevailing internal parasitic diseases among some cultured freshwater fishes in Kafr El-Sheikh province. [Master's thesis]. Egypt: Tanta University; 2002.

27. Boomker J. Parasites of South African freshwater fish. I. Nematodes of the catfish [Clarias gariepinus (Burchell, 1822)] from the Hartbeespoort Dam. Onderstepoort J Vet Res. 1982; 49:41-51.

28. Barson M, Avenant-Oldewage A. Nematode parasites of Clarias gariepinus (Burchell, 1822) from the Rietvlei Dam, South Africa. Onderstepoort J Vet Res. 2006; 73:87-94.

29. Eissa IA, Badran AF, Mohamed S Y, Abd el mola H I. Enteroparasitic infestation and the associated pathological lesions in Clarias gariepinus at Ismailia province. J Agricul Vet Sci. 2010; 3(1):21-32.

30. World Register of Marine Species (WoRMS) 2012. marinespecies.org, version 10/2012 [Internet].Available from:http://www.marinespecies.org/.

31. Rewaida Abdel-Gaber, Manal El Garhy, Kareem Morsy. Prevalence and Intensity of Helminth Parasites of African Catfish Clarias gariepinus in Lake Manzala, Egypt. Advances Biosci Biotech. 2015; 6:464-469. http://dx.doi.org/10.4236/abb.2015.67048

32. Ajala O, Olumuyiwa, Fawole O Olatunde. Multiple infections of helminthes in the alimentary system of Clarias gariepinus (Burchell, 1822) in a tropical reservoir. Int J Fisheries Aquacul. 2014;6(6):62-70.

33. Schaperclaus W. Fish diseases Volume (II). A. A. Balkema, Roterdam, Berlin; 1992.

34. Moravec F. The development of Paracamallanus cyathopharynx (Baylis, 1923) (Nematoda:Camallanidae). Folia Parasitologica (Praha).1974; 21, 333-343.

35. Awatef HH. Studies on the trematodal and cestodal diseases in cultured freshwater fish in Kafr El-Sheikh Governorate. [Ph. D. Thesis].Egypt; Faculty of Veterinary Medicine; Kafrelsheikh University; 2014.

36. Abdou NE. Studies on the anisakid nematode juveniles infecting some Red Sea fishes in Egypt. J Invertebrate Zool Parasitol. 2005; 47:147160.

37. Barson M. The occurrence of Contracaecum sp. larvae (Nematoda:Anisakidae) in the catfish, Clarias gariepinus (Burchell) from Lake Chivero, Zimbabwe. Onderstepoort J Vet Res. 2004; 71:35-39.

38. Efole ET, Domwam, Tomedi EM, Zango P, Tiogue C, Mikolasek o, Tcthoumbouej. Infestation of African catfish Clarias gariepinus (Burchell, 1822) (Teleostei, Clariidae ) by Nematodes Eustrongylides (Dioctophymatidae) and Contracaecum (Anisakidae) in the Mbôplains, West, Cameroon. IOSR J Agricul Vet Sci. 2016; 9(12):3944. DOI: $10.9790 / 2380-0912023944$

39. Marcogliese DJ. The impact of climate change on the parasites and infectious diseases of aquatic animals. Rev Sci Tech. 2008; 27:467484.

40. Hamouda AH, Sorour ShS, El-Habashi NM, El-Hussein AA. Parasitic Infection with Emphasis on Tylodelphys spp. as New Host and Locality Records in Nile Perch; Lates niloticus from Lake Nasser, Egypt. World Vet. J.2018; 8(1): 19-33. 